\title{
The level of the general reactivity of erythrocytes membranes in rats with combined action of infrasound
}

\author{
Sultan Tuleukhanov ${ }^{1}$, Yuri Shapovalov ${ }^{1}$, Askar Mautenbaev ${ }^{1}$, Marzhan Kulbayeva ${ }^{1}$, Zhanna \\ Abdrassulova $^{1^{*}}$ \\ ${ }^{1}$ Al-Farabi Kazakh National University, al-Farabi Ave. 71, 050040 Almaty, Republic of Kazakhstan
}

\begin{abstract}
This study focuses on the level of the general reactivity of erythrocytes membranes in rats with combined action of infrasound. The effect on biological features was investigated through the experiments on the rats. Comparative analysis of immunological parameters, the permeability of erythrocyte membranes and the electrical conductivity of blood in rats under the effects of infrasound at a frequency of $15 \mathrm{~Hz}$ and intensity $11 \mathrm{~dB}$ through exposure time of 3-3600 seconds allowed proving that infrasound causes nonspecific changes at the cellular and subcellular levels of the organism. There was used many different technologies and methods. Based on the obtained results, direct indirect and combined effect of infrasound immunological parameters had clearly increased the total count of leukocyte index and all parameters of differential count of leukocytes as well as appearance immature products in the peripheral blood.
\end{abstract}

\section{Introduction}

Exposure to infrasound has been found to induce modest temporary threshold shift (TTS) in some subjects for example, Jerger et al. [1] reported that repeated exposures to $2-12 \mathrm{~Hz}$ at 119-144 dB for three minutes induced TTS of $10-22 \mathrm{~dB}$ at $3-8 \mathrm{kHz}$, with full recovery after a few hours, in 11 out of 19 subjects tested. Using a piston-phone coupled to the ear via an earmuff, Nixon observed TTS that persisted for about 30 minutes in about one-third of volunteers exposed to an $1 \mathrm{~S} \mathrm{~Hz}$ signal at $135 \mathrm{~dB}$. Subjects were exposed for six periods of five minutes with a one to two-minute rest period between each. Similar responses have been reported using higher frequencies [2]. Overall, these studies suggest that infrasound may induce a temporary shift in hearing threshold in some subjects, but recovery is usually rapid and complete.

Rats and guinea pigs ( 5 test animals, 2 controls per group) were exposed infrasound (4 to $16 \mathrm{~Hz}$ ) at 90 to $145 \mathrm{~dB}$ for $3 \mathrm{~h} /$ day for 45 days; and tissues were collected on days 5, 10, 15, 25 , and 45 for path morphological examination. A single exposure to 4 to $10 \mathrm{~Hz}$ at 120 to $125 \mathrm{~dB}$ led to short-term arterial constriction and capillary dilatation deformation, mitochondrial damage, and other pathologies. Effects were most marked after $10-$ to $15-\mathrm{Hz}$

\footnotetext{
${ }^{*}$ Corresponding author: Zhanna.Abdrassulova@kaznu.kz
} 
exposures at 135 to $145 \mathrm{~dB}$. Regenerative changes were observed within 40 days after exposure [3]. Prolonged exposure (up to 60 days) of rats to $8 \mathrm{~Hz}$ at $100 \mathrm{~dB}$ led to significant biochemical and morphological changes in the blood and tissues. Dosing the rats with even small doses of imidazole (ethimizole and T-5) provided a marked protective effect, acting on the antioxidant status of the body. In the experiments, male rats of no specific strain (10/group) were exposed to $8 \mathrm{~Hz}$ at $100 \mathrm{~dB}$ for $3 \mathrm{~h} /$ day for 2 months with and without dosing with ethimizole or T-5, which were also tested alone. The authors reported variable effects of the imidazoles on infrasound-induced changes in erythrocyte concentrations of catalase, malonic acid dialdehyde, and glutathione reductase and the plasma concentrations of alanine aminotransferase, aspartate aminotransferase, and ceruloplasmin. Infrasound exposure induced tissue changes (destructive and atrophic changes of a focal character without marked gros disturbances in the lungs, liver, and kidneys as well as foci of proliferation of stroma clements) that were moderated by the imidazole. Only insignificant per bronchi infiltration was noted after dosing. Dystrophic changes in the liver, heart, kidneys adrenals, and testicles were lowered to a minimum [4]

Male rats (10/group) exposed to infrasound $(8 \mathrm{~Hz})$ at 100 and $140 \mathrm{~dB}$ for $3 \mathrm{~h} /$ day for 5 , 10,15 , or 25 days showed constriction of all parts of the conjunctival vascular bed within 5 days. The decrease in the lumen of the capillaries was accompanied by swelling of the cytoplasm and the nuclei of the endotheliocytes. The capillaries, precapillaries, and arterioles became crimped. Morphological changes were reported in the vessels after exposure for 10, 15, and 25 days. After 25 days. increased permeability of the blood vessels led to swelling of tissues and surrounding capillaries and to perivascular leukocyte infiltration. Significant aggregates of formed elements of the blood were observed in the large vessels [5].

In studies of male rats (10/group) exposed to low-frequency noise noise or 25 infrasound for $3 \mathrm{~h} /$ day for $5,10,15$, or 25 days, changes in erythrocyte membrane permeability and enzyme concentrations depended primarily on the frequency and less on the intensity. The most sensitive index of injury was the increase in alanine aminotransferase activity in the serum. The increase in erythrocyte membrane permeability coincided with the increase of alanine aminotransferase, but the latter persisted longer. The alanine aminotransferase activity of liver tissue was lowered by the 15 th day with $8 \mathrm{~Hz}$ at $140 \mathrm{~dB}$ and by the 15 th to 25th day with $16 \mathrm{~Hz}$ at $150 \mathrm{~d}$. the heart, exposure to $8 \mathrm{~Hz}$ at $140 \mathrm{~dB}$ lowered alanine aminotransferase activity by the 15 th day yet increased the activity by the 25 th day.

\section{Materials and method}

The model of infrasonic device that used in this work is IFS-1 Production Company TOO Batysmedtech, Uralsk (Kazakhstan). Range of radiated frequencies - from 13 to $30 \mathrm{~Hz}$. Relative error of established frequency no more $\pm 2 \%$. Level of sound pressure generated by installation is 10.9 to $14.0 \mathrm{~dB}$ at direct contact of a radiator to exposed animals. Installation works from a network of alternation current of frequency $50 \mathrm{~Hz}$ with rated voltage $220 \mathrm{~V}$ at a deviation of tension $10 \%$ from nominal value. Power consumption installation is no more than 160 wt. Establishment time of installation does not exceed 15 minutes after its inclusion [6]. In this work 650 male of albino rats, each of average weight $250 \pm 10$ gm were used. The animals were divided into 3 groups. Exposure to infrasonic waves for each group was carried out at different three-duration time 3,10,20 minutes. The blood samples were collected from all animals before the exposure as self-control and after 3, 6, 12, 30 and 60 days.

Exposure to infrasonic waves for each group was carried out at different duration times 3, 10, 30, 60, 180, 600, 1800 and 3600 seconds. The blood samples were collected from all animals before the exposure as control and after the exposure. The temperature inside the laboratory varied between $25^{\circ} \mathrm{C}$ and $27^{\circ} \mathrm{C}$. Lighting condition were natural light from large 
windows during the day and complete darkness during the night. Food was available (24 h/day) [7].

Bio-impedance, bioelectricity and the electrical properties of tissue are much about the same things. Bio-impedance (the ability to oppose (impede) electric current flow) deals with some passive electrical propperties of tissue. Bioelectricity deals with the ability of tissue to generate electricity, as for instance done by the heart (electrocardiography (ECG)). This electricity is endogenic means that, the tissue itself generates it [8-11]. Bioelectricity is also, about how tissue can be controlled by electricity. Such electricity together with the electricity used for measuring bio impedance is exogenic (i. e. with externally applied electricity). Bioelectricity is about the electrical phenomena of life processes, and is a parallel to the medical subject electrophysiology. One basic mechanism is the energy consuming cell membrane ion pumps polarizing a cell, and the action potential generated if the cell is excited and ion channels open.The research of domestic and foreign scientists was also studied and the methods and technologies for conducting this kind of research were based [12-15].

\section{Results and Discussion}

For a more complete of understanding the mechanisms of actions of infrasound on the body, experiments were investigated on rats after combined exposure to infrasound and that was by exposure the body to infrasound as a direct exposure in addition exposure the water to infrasound as indirect effect than the infrasound treated water introduced to the irradiated rats for drinking. The results of experiments on the permeability of erythrocyte membranes are shown in Tables 1.2 and Figures 1,2.

As can be seen from Table 1, along with the decrease of the studied parameters in some cases, noted an increase compared with control values. It's observed that reduction in the percent of hemolysis at all times of exposure at concentrations $100 \%, 60 \%$ and $50 \%$ of $\mathrm{NaCl}$ $(0,9 \%)$. An increase in the percent of hemolysis observed at concentration $66 \%$ of $\mathrm{NaCl}$ $(0,9 \%)$ and exposure times 60 and 180 seconds.

At concentration $45 \%$ of $\mathrm{NaCl}(0,9 \%$ ( found an increase in the percent of hemolysis at exposure time 360 seconds, and at concentrations of $40 \%$ found increase at $60 \mathrm{sec}, 600 \mathrm{sec}$, $1800 \mathrm{sec}$ and $3600 \mathrm{se}$, and at concentrations of $35 \%$ found increase at $30 \mathrm{sec}, 600 \mathrm{sec}, 1800$ and $3600 \mathrm{sec}$.

Primarily we have analyzed the cases of deviation (increase or decrease the percent of hemolysis of red blood cell membranes from the norm). The data obtained indicate that these changes depend primarily on the concentration of $\mathrm{NaCl}(0.9 \%)$ and on the exposure time of radiation to infrasound secondly and with lesser degree.

The clearest and pronounced changes in the studied parameters were observed at concentrations of $40 \%$ and $35 \%$. At $100 \%, 60 \%$ and $50 \%$ concentrations of $\mathrm{NaCl}(0.9 \%)$, there was practically no increase in percent of hemolysis of red blood cell membranes. At all concentrations of $\mathrm{NaCl}(0.9 \%)$ except at $100 \%$ and $60 \%$ increase in hemolysis of red blood cell membranes is observed at exposure time 30 seconds. At concentrations of $100 \%, 60 \%$ and $50 \%$ changes were a little depending on the exposure time of infrasound effect. Increase of percent of hemolysis of red blood cell membrane indicates the presence of damage to the membrane structure. Nevertheless, in some cases, found a decrease of the studied parameters in comparison with control, especially at concentrations of $100 \%, 60 \%$ and $50 \%$ and this may reflect more profound changes.

From figure 1, it shows that the percent of hemolysis of red blood cell membranes, depending on the concentration of $\mathrm{NaCl}(0.9 \%)$ as in control and in the experimental groups of animals really varies depending on the exposure time to infrasound. Change in the percent of hemolysis depends on the time of exposure to infrasound and concentration of $\mathrm{NaCl}$ 
$(0.9 \%)$. Thus, more close correlation between percent of hemolysis and $\mathrm{NaCl}$ concentration $(0.9 \%)$ revealed at exposure to 30 seconds and 60 seconds and less - at exposure time to 180 seconds, 600 seconds, 1800 seconds and 3600 seconds. The obtained results may indicate a direct effect of infrasound on the structure of erythrocyte membranes, ie yet another mechanism of action of infrasound on the body. Table 1 it shows that the values of the area, height and width of the Gaussian peaks, H50 in the experimental groups of rats which have a wavelike character, i.e. the fall, then rise compared with control animals. Changes in membrane permeability depend on the exposure effects to infrasound. Thus, the indicator area is reduced at exposure $30 \mathrm{sec}, 60 \mathrm{sec}$ and $1800 \mathrm{sec}$, while exposures at 3 seconds, 10 seconds, 180 seconds, 600 seconds and 3600 seconds increase. Level of height is lowered at exposure 180 seconds, while the other exposures of radiation increase. The value of width is increased at exposure 3 seconds, 10 seconds, 180 seconds, 1800 seconds, and decrease at 30 $\mathrm{sec}, 60 \mathrm{sec}, 600 \mathrm{sec}, 3600 \mathrm{sec}$. H50 is reduced at exposure 3 seconds, 10 seconds, 30 seconds and 180 seconds, while in the other increase. Thus, there is a great sensitivity to the effects of infrasonic vibrations on all parameters of Gaussian curves of the permeability of erythrocyte membranes, especially the width and H50.

From Figure 2 shows that the dependence of the differential rate of hemolysis in control and experimental groups of animals on the concentration of $\mathrm{NaCl}(0.9 \%)$ at different times of exposures to combined effects of infrasound are multidirectional and complex. Thus, the greatest dependence observed at exposures $30 \mathrm{sec}$ and $60 \mathrm{sec}$, while at other times of exposure revealed weak correlation between the differential rates of hemolysis and exposure times to infrasound.

Table 1. The Percent of hemolysis of RBC membranes at different concentrations of $\mathrm{Na} \mathrm{Cl}(0,9 \%)$ before and after combined exposure to infrasound for different periods of exposure (Group C).

\begin{tabular}{|c|c|c|c|c|c|c|c|c|}
\hline \multirow[b]{3}{*}{$\begin{array}{l}\text { Time } \\
\text { exposure } \\
\text { (sec) }\end{array}$} & \multicolumn{8}{|c|}{ Hemolysis of Red Blood Cells at different concentrations of $\mathrm{NaCl}(0,9 \%)$} \\
\hline & $100 \%$ & $60 \%$ & $55 \%$ & $50 \%$ & $45 \%$ & $40 \%$ & $35 \%$ & $0 \%$ \\
\hline & 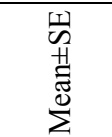 & 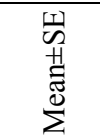 & 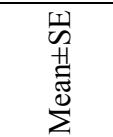 & $\begin{array}{l}\text { 데 } \\
\text { से } \\
\text { च्ञ } \\
\sum_{\Sigma}^{\infty}\end{array}$ & $\begin{array}{l}\text { In } \\
\text { H } \\
\text { त् } \\
\sum_{\Sigma}^{\infty}\end{array}$ & 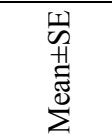 & 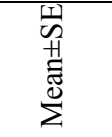 & 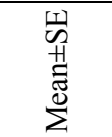 \\
\hline Control & $\begin{array}{c}2,75 \pm \\
0,47\end{array}$ & $\begin{array}{c}3,02 \pm \\
0,74\end{array}$ & $\begin{array}{c}4,56 \pm \\
0,71\end{array}$ & $\begin{array}{c}9,28 \pm \\
1,58\end{array}$ & $\begin{array}{c}32,01 \pm \\
1,22\end{array}$ & $\begin{array}{c}49,55 \pm \\
1,98\end{array}$ & $\begin{array}{c}79,34 \pm \\
1,58\end{array}$ & $\begin{array}{c}100,00 \pm \\
0,00\end{array}$ \\
\hline 3 & $\begin{array}{c}1,58 \pm \\
0,13\end{array}$ & $\begin{array}{l}1,89 \pm \\
0,15^{*}\end{array}$ & $\begin{array}{c}2,50 \pm \\
0,25^{* *}\end{array}$ & $\begin{array}{l}4,34 \pm \\
1,00^{*}\end{array}$ & $\begin{array}{c}14,90 \pm \\
2,50 * * *\end{array}$ & $\begin{array}{c}26,72 \pm \\
2,50 * * *\end{array}$ & $\begin{array}{l}62,39 \pm \\
3,00 * *\end{array}$ & $\begin{array}{c}100,00 \pm \\
0,00\end{array}$ \\
\hline 10 & $\begin{array}{c}1,11 \pm \\
0,13 * * *\end{array}$ & $\begin{array}{c}1,41 \pm \\
0,15^{* *}\end{array}$ & $\begin{array}{c}3,18 \pm \\
0,25 *\end{array}$ & $\begin{array}{c}5,37 \pm \\
1,00\end{array}$ & $\begin{array}{c}13,02 \pm \\
2,50 * * *\end{array}$ & $\begin{array}{r}29,51 \pm \\
2,50^{* * *}\end{array}$ & $\begin{array}{c}74,26 \pm \\
3,00\end{array}$ & $\begin{array}{c}100,00 \pm \\
0,00\end{array}$ \\
\hline 30 & $\begin{array}{c}1,65 \pm \\
0,13^{* *}\end{array}$ & $\begin{array}{c}2,23 \pm \\
0,15\end{array}$ & $\begin{array}{c}2,97 \pm \\
0,25 * *\end{array}$ & $\begin{array}{c}6,76 \pm \\
1,00\end{array}$ & $\begin{array}{l}20,81 \pm \\
2,50^{* *}\end{array}$ & $\begin{array}{c}49,26 \pm \\
3,50\end{array}$ & $\begin{array}{c}79,90 \pm \\
3,00\end{array}$ & $\begin{array}{c}100,00 \pm \\
0,00\end{array}$ \\
\hline 60 & $\begin{array}{c}1,50 \pm \\
0,15^{* *}\end{array}$ & $\begin{array}{c}3,03 \pm \\
0,13\end{array}$ & $\begin{array}{c}5,45 \pm \\
0,25\end{array}$ & $\begin{array}{c}9,12 \pm \\
2,50\end{array}$ & $\begin{array}{c}27,54 \pm \\
1,00\end{array}$ & $\begin{array}{l}63,67 \pm \\
2,50 * *\end{array}$ & $\begin{array}{c}77,07 \pm \\
3,00\end{array}$ & $\begin{array}{c}100,00 \pm \\
0,00\end{array}$ \\
\hline 180 & $\begin{array}{c}2,42 \pm \\
0,25\end{array}$ & $\begin{array}{c}2,96 \pm \\
0,13\end{array}$ & $\begin{array}{c}5,95 \pm \\
0,15^{* *}\end{array}$ & $\begin{array}{c}8,61 \pm \\
1,00\end{array}$ & $\begin{array}{c}28,95 \pm \\
2,50\end{array}$ & $\begin{array}{c}39,31 \pm \\
2,50 *\end{array}$ & $\begin{array}{r}58,07 \pm \\
3,00^{* * * *}\end{array}$ & $\begin{array}{c}100,00 \pm \\
0,00\end{array}$ \\
\hline 600 & $\begin{array}{c}1,54 \pm \\
0,13 * *\end{array}$ & $\begin{array}{c}1,63 \pm \\
0,15^{* *}\end{array}$ & $\begin{array}{c}2,07 \pm \\
0,25 * * *\end{array}$ & $\begin{array}{l}4,39 \pm \\
1,00^{*}\end{array}$ & $\begin{array}{l}22,15 \pm \\
2,50 * *\end{array}$ & $\begin{array}{c}94,69 \pm \\
2,50 * * *\end{array}$ & $\begin{array}{l}96,27 \pm \\
3,00 * *\end{array}$ & $\begin{array}{c}100,00 \pm \\
0,00\end{array}$ \\
\hline 1800 & $\begin{array}{c}1,73 \pm \\
0,13^{* *}\end{array}$ & $\begin{array}{c}1,36 \pm \\
0,15^{* *}\end{array}$ & $\begin{array}{c}2,87 \pm \\
0,25^{* *}\end{array}$ & $\begin{array}{l}4,39 \pm \\
1,00^{*}\end{array}$ & $\begin{array}{c}12,67 \pm \\
2,50 * * *\end{array}$ & $\begin{array}{c}83,38 \pm \\
2,50 * * *\end{array}$ & $\begin{array}{c}88,93 \pm \\
3,00^{*}\end{array}$ & $\begin{array}{c}100,00 \pm \\
0,00\end{array}$ \\
\hline 3600 & $\begin{array}{l}1,86 \pm \\
0,13 *\end{array}$ & $\begin{array}{c}1,67 \pm \\
0,15^{* *}\end{array}$ & $\begin{array}{c}2,95 \pm \\
0,25^{* *}\end{array}$ & & $\begin{array}{c}60,15 \pm \\
2,50 * * *\end{array}$ & $\begin{array}{c}96,89 \pm \\
2,50 * * *\end{array}$ & $\begin{array}{c}98,57 \pm \\
3,00 * * *\end{array}$ & $\begin{array}{c}100,00 \pm \\
0,00\end{array}$ \\
\hline One & NOVA & & & & & & & \\
\hline F- ratio & 5,67 & 6,22 & 17,56 & 2,43 & 41,96 & 121,19 & 22,94 & - \\
\hline
\end{tabular}




\begin{tabular}{|l|c|c|c|c|c|c|c|c|}
\hline $\mathrm{P}$ - value & $0,01 * * *$ & $0,01 * *$ & $0,00^{* *}$ & $0,10^{*}$ & $0.00 * * *$ & $0,00^{* * *}$ & $0,00 * * *$ & - \\
\hline \multicolumn{8}{|c|}{ Where - $* \mathrm{P} \leq 0,05 ; * * \mathrm{P} \leq 0,01 ; * * * \mathrm{P} \leq 0,001$} \\
\hline
\end{tabular}
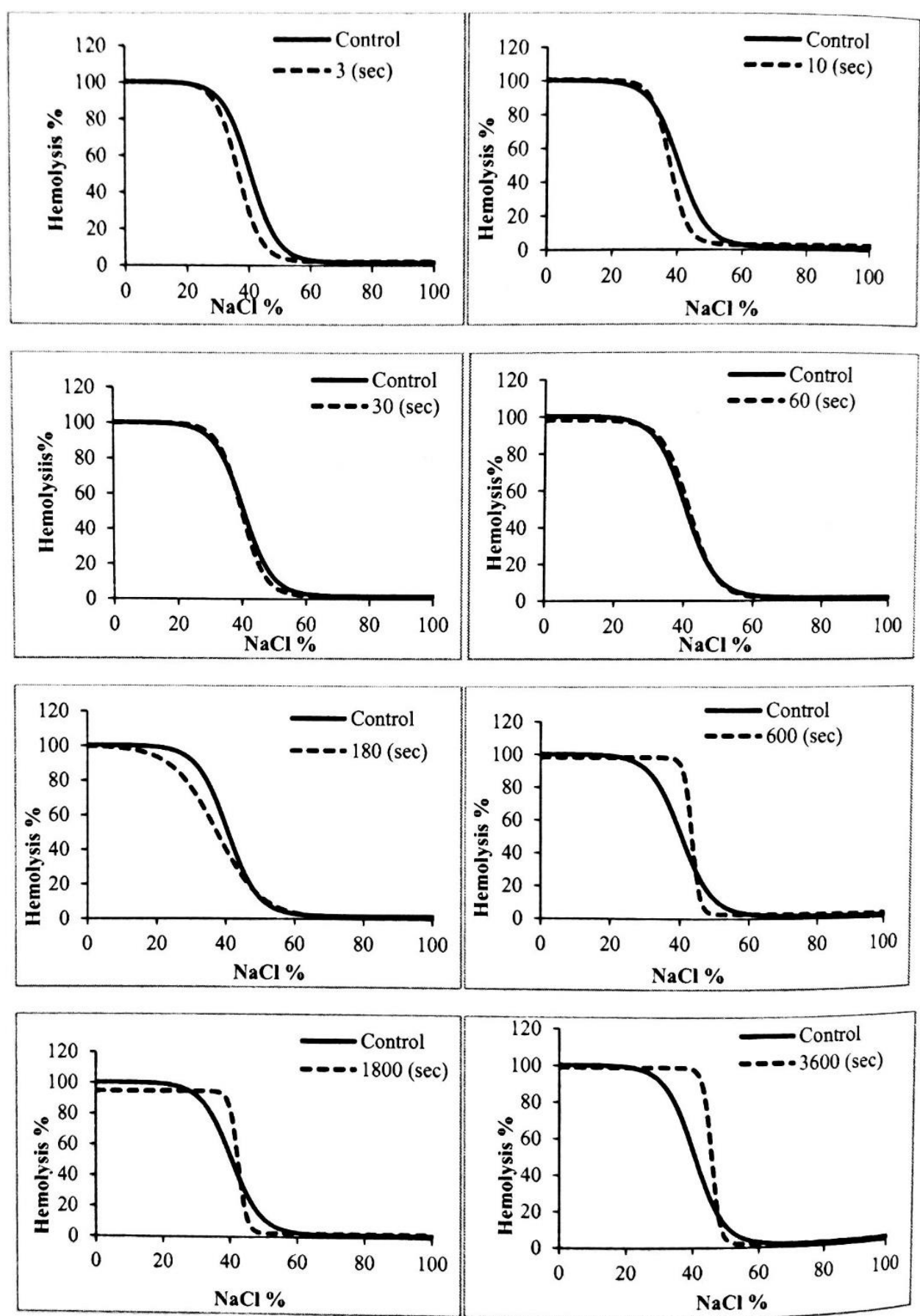
Fig. 1. Hemolysis curves of red blood cell membranes at different concentrations of $\mathrm{NaCl}(0,9 \%)$ before and after combined exposure to infrasound for different periods of exposure (Group C).
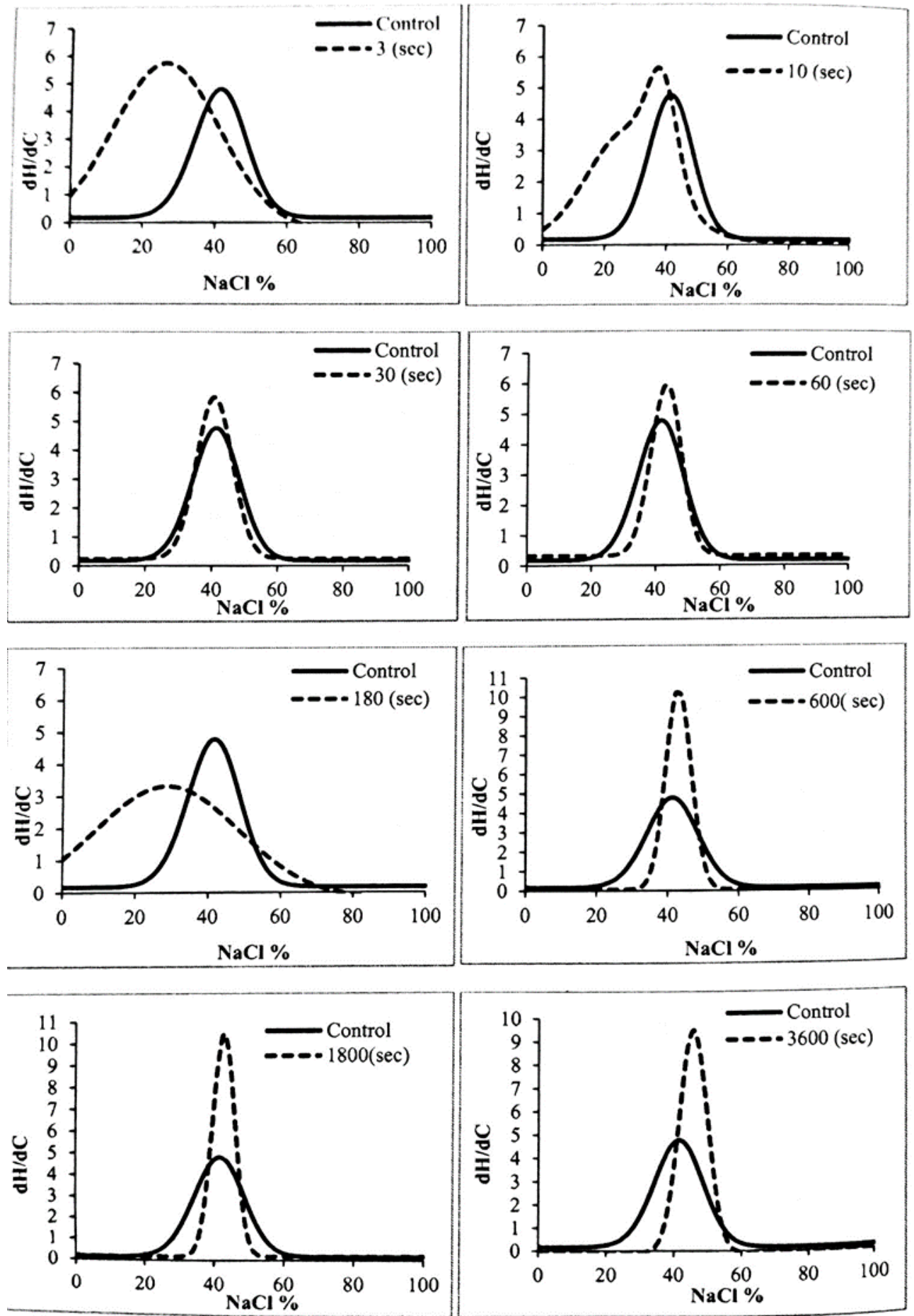
Fig. 2. The rate of hemolysis versus $\mathrm{NaCl}(0,9 \%)$ for control and at different periods of exposure to combined exposure to infrasound for group $\mathrm{C}$.

Table 2. Area, width, height and H50 of the Gaussians peaks for control and after different periods of indirect exposure to infrasound for group B.

\begin{tabular}{|c|c|c|c|c|}
\hline \multirow{2}{*}{$\begin{array}{c}\text { Time } \\
\text { exposure } \\
(\mathrm{sec})\end{array}$} & Area & Width & Height & $\mathrm{H} 50$ \\
\hline & Mean \pm SE & Mean \pm SE & Mean \pm SE & Mean \pm SE \\
\hline Control & $83,00 \pm 4,88$ & $14,36 \pm 1,25$ & $4,62 \pm 0,13$ & $40,38 \pm 0,11$ \\
\hline 3 & $222,08 \pm 5,05 * *$ & $29,55 \pm 0,29 * *$ & $6,00 \pm 0,20 * * *$ & $36,53 \pm 0,44 * * *$ \\
\hline 10 & $150,69 \pm 80,26$ & $17,80 \pm 8,35$ & $6,50 \pm 0,55 * * *$ & $37,60 \pm 0,36 * * *$ \\
\hline 30 & $76,91 \pm 3,35$ & $10,95 \pm 0,40$ & $5,60 \pm 0,04 * *$ & $39,81 \pm 0,44$ \\
\hline 60 & $66,84 \pm 1,67$ & $9,48 \pm 0,15$ & $5,62 \pm 0,05^{* *}$ & $41,43 \pm 0,40$ \\
\hline 180 & $172,34 \pm 1,69 * *$ & $39,34 \pm 0,14 * * *$ & $3,50 \pm 0,02 * *$ & $37,27 \pm 0,81 * * *$ \\
\hline 600 & $92,96 \pm 2,75$ & $7,19 \pm 0,20$ & $10,32 \pm 0,02 * * *$ & $43,49 \pm 0,18 * * *$ \\
\hline 1800 & $42,62 \pm 0,00 * *$ & $42,62 \pm 0,00 * * *$ & $42,62 \pm 0,00 * * *$ & $42,62 \pm 0,00 * *$ \\
\hline 3600 & $100,22 \pm 2,88$ & $8,35 \pm 0,08$ & $9,57 \pm 0,19 * * *$ & $45,51 \pm 0,08 * * *$ \\
\hline \multicolumn{5}{|c|}{ One way ANOVA } \\
\hline F- ratio & 7,75 & 23,65 & 6169,53 & 60,11 \\
\hline $\mathrm{P}$-value & $0,00^{* * * *}$ & $0,00^{* * * *}$ & $0,00^{* * * *}$ & $0,00^{* * *}$ \\
\hline \multicolumn{5}{|c|}{ Where $-* \mathrm{P} \leq 0,05 ; * * \mathrm{P} \leq 0,01 ; * * * \mathrm{P} \leq 0,001$} \\
\hline
\end{tabular}



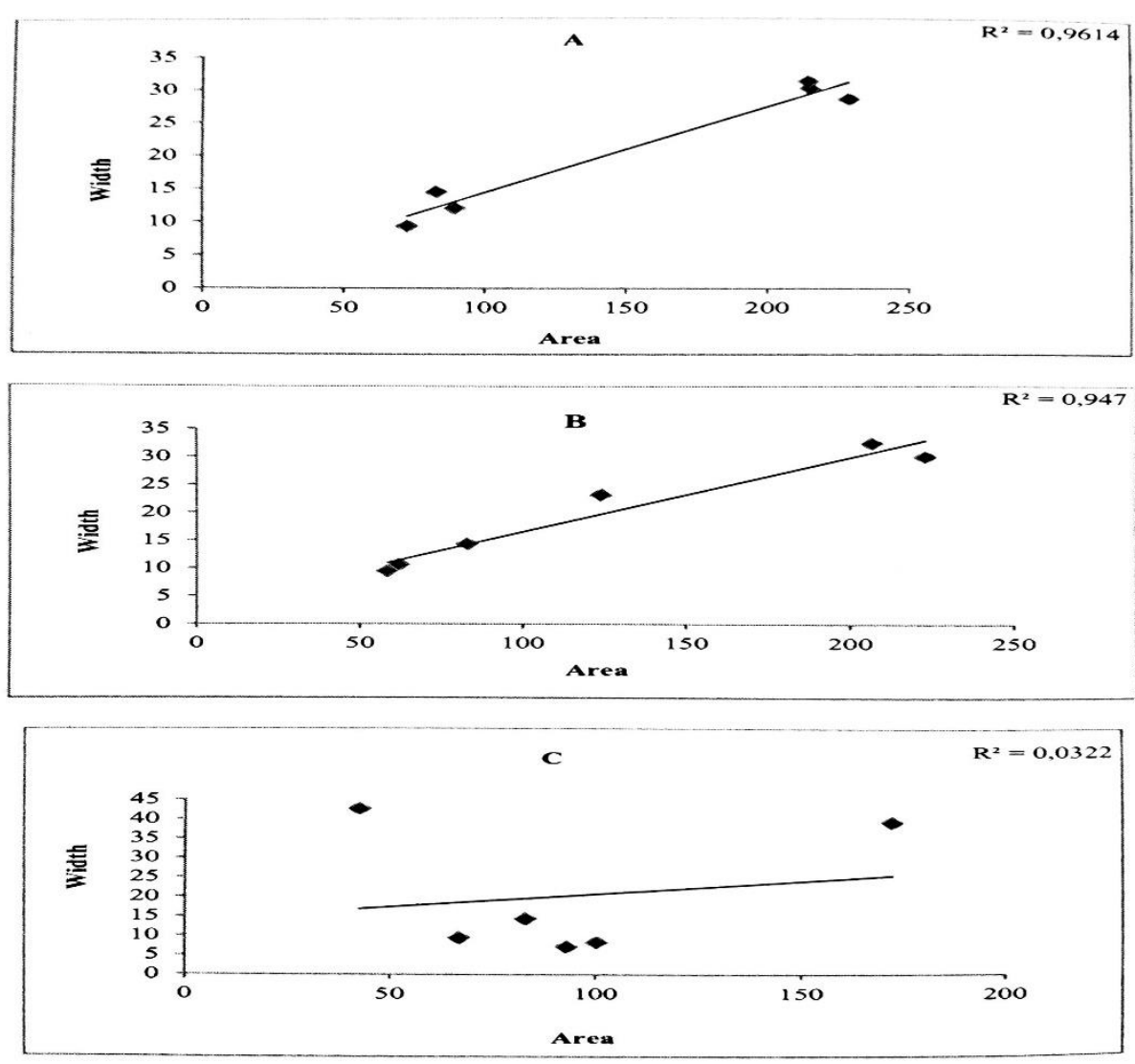

Fig. 3. Correlation between the area under Gaussian curve and the width at half-maximum Gaussian curve in groups (A, B, C). 

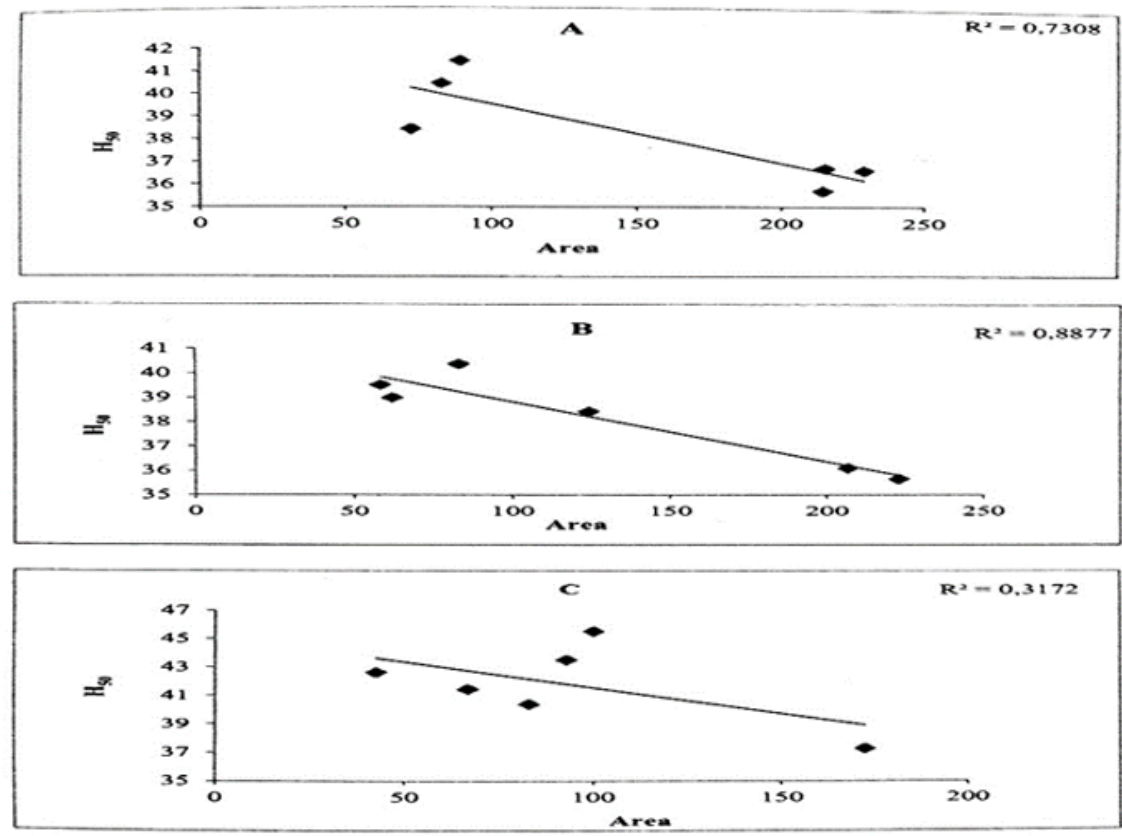

Fig. 4. Correlation between $\mathrm{H} 50$ - $(\mathrm{NaCl}$ concentration which produce $50 \%$ hemolysis of red blood cell membranes) and the area under the Gaussian curve in groups (A, B, C).
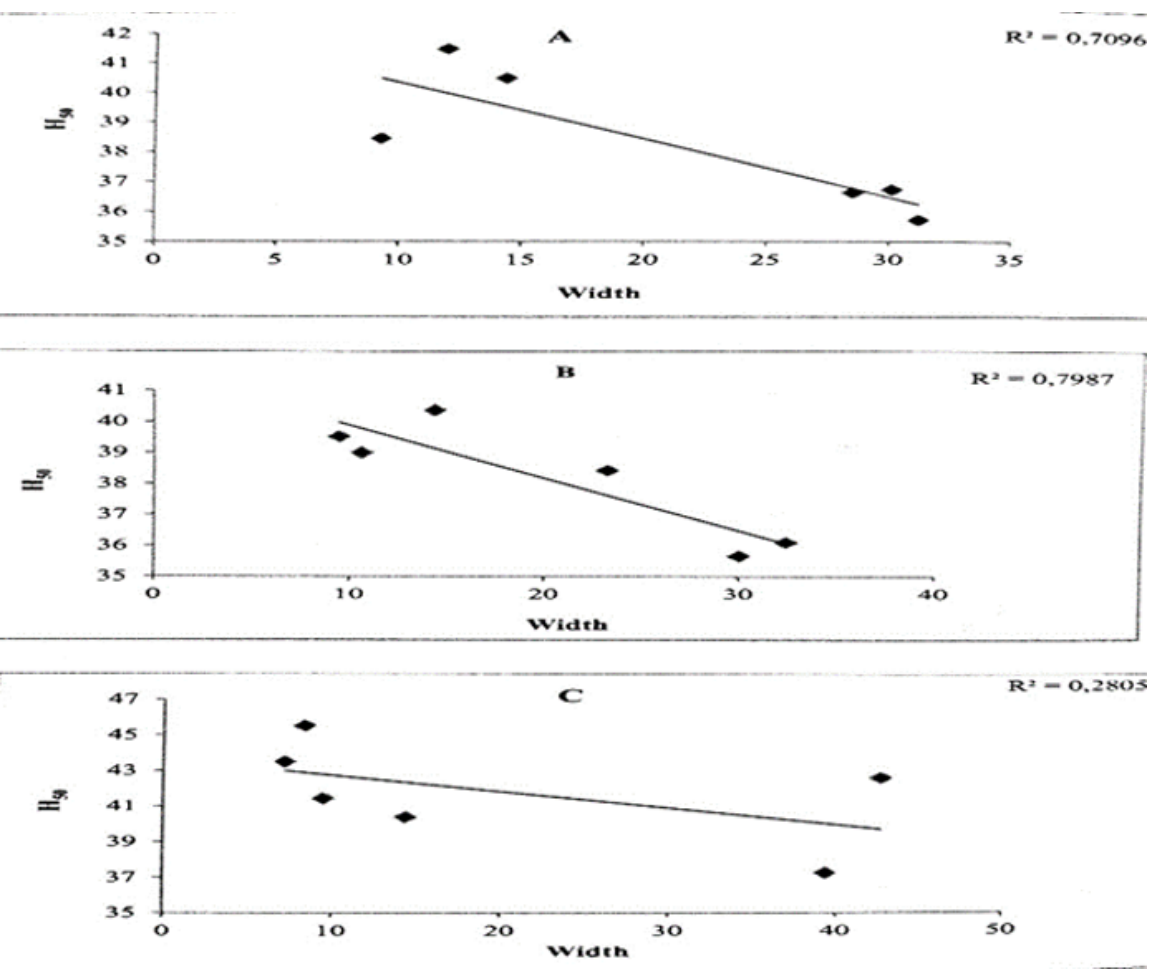
Fig. 5. Correlation between $\mathrm{Hso}-(\mathrm{NaCl}$ concentration that produce $50 \%$ hemolysis of red blood cell membranes) and the width at half-maximum Gaussian curve in groups of animals (A, B, C).

Thus is established the nonlinear relationship between the differential parameters of hemolysis and exposure times to infrasound. The data obtained may indicate the multidirectional nature of infrasound on the permeability of erythrocyte membranes.

It is calculated also the values of the correlation relationships between indicators of the area and the width of the Gaussian peaks and (H50) in different experimental animals (A, B, C).Comparative analysis of the correlation parameters of width and area of Gaussian peaks and (H50) in different groups of experimental animals are presented in Figures 3, 4 and 5. From figure 3 it showed that between the width and area of Gaussian peaks in groups A and $\mathrm{B}$, a high correlation relation, and in group $\mathrm{C}$ correlation relation between these indicators are not available, there are not statistically significant.

From figure 4, it showed that the high correlation relation between $\mathrm{H} 50$ and the area of Gaussian peak in groups A and B while for group C correlation relation was weak. The correlation relationship between the $\mathrm{H} 50$ and the area is weaker than the correlation between the width and area (see Figure 3 and 4). As shown in Figure 5 the correlation relation between the parameters $\mathrm{H} 50$ and the width at half maximum of Gaussian curve, as in previous figures, it is observed a high correlation relation in groups A and B and a weak correlation relation in group C.From these results, it can be concluded that between areas under the curves, widths at half maximum there is a proportional relation, and H50 is inversely proportional to the area-identified link.

\section{Conclusion}

In summary, it must be emphasized that the changes in the permeability of erythrocyte membranes of rats' blood in the combined effects of infrasound are expressed clearly enough. On the other hand, the complex and multidirectional nature of the factors influencing the permeability of the membranes requires a combined use of several methods for an accurate evaluation of the observed shifts.

Thus, as the summary on the study of the influence of infrasound on the permeability of erythrocyte membrane (PEM), one can draw the following conclusions about effects of direct, indirect and combined exposure to infrasound for A direct effect on cellular structures of the body:

- change some of the biophysical and metric indices of erythrocyte membranes as a function of the concentration of $\mathrm{NaCl}(0.9 \%)$ and exposure effects;

- significant damage to the Organizational Structure and function of membranes;

- the most significant changes of PEM under the influence of infrasound exposure were at 3 seconds and 180 seconds, 1800 seconds and 3600 seconds;

- a high correlation between the width at half maximum of Gaussian curve and the area under the curve of Gaussian curve, and $\mathrm{H} 50(\mathrm{NaCl}$ concentration which produce $50 \%$ hemolysis of red blood cell membranes) in-group $\mathrm{A}$ and $\mathrm{B}$ while in-group $\mathrm{C}$ found no correlation.

Although of undesired biological effects of infrasound that detected through our study, still there are many others beneficial effects should be taken in our consideration. Many hospitals around the world used infrasound in the treatment of diseases diseases but it should be taken into account using frequency, time of exposure and intensity to avoid the expected harmful effects after exposure to these waves.

Although of undesired biological effects of infrasound that deteeted through our study, still there are many others beneficial effects should be taken in our consideration. Many hospitals around the world used infrasound in the treatment of some discuses based on its 
properties. We advise to use this technique in treatment of diseases but it should be taken into account using frequency, time of exposure and intensity to avoid the expected harmful effects after exposure to these waves.

Finally, we recommended that many high quality researches needed w understand the way of interaction of infrasound with biological systems establish the standers of exposure from this wave.

Based on obtained results, direct indirect and combined effect of infrasound immunological parameters had clearly increased the total count of leukocyte index and all parameters of differential count of leukocytes as well as appearance immature products in the peripheral blood. A comparative study of the permeability of erythrocyte membranes after direct, indirect and combined irradiation infrasound showed that: increase in the percent of hemolysis, the rate of hemolysis and maximum rate of hemolysis of erythrocyte membrane. This result reflects increase in the fragility of the membrane of erythrocytes and the abnormal increase is the membrane elasticity, as well as the increase in the electric conductivity of blood Morphological characteristics of leukocytes in experimental groups compared wit control clearly changed after direct indirect and combined exposure to infrasound frequency at $15 \mathrm{~Hz}$ and with intensity of $11 \mathrm{~dB}$. Recommendations for concrete use of research results: Results of the reaction of immunological parameters of the organism under the influence of infrasound at a frequency of $15 \mathrm{~Hz}$ and intensity $11 \mathrm{~dB}$ suggest that infrasound at a specified frequency and intensity has a powerful effect on the immune status of the organism. Therefore should take effective protective measures against this radiation Results of the study of the permeability of erythrocyte membranes in control and experimental groups will be the basis for practical use as an estimate of magnitude of the effect of infrasound on the body. Studies on the effect of infrasound on the electrical conductivity of the blood of animals can be used as a theoretical and practical basis for assessing mechanisms of action of infrasound on the body.

\section{References}

1. J. Jerger, B. Alford, A. Coats, J. Speech Hear Res., 9(1), 150-160 (1966)

2. J.H. Mills, J.D. Osguthorpe, C.K. Burdick, J.H. Patterson, B. Mozo, J. Acoust Soc Am., 73(3), 918-923 (1983)

3. S.V. Alekseev, V.V. Glinchikov, V.R. Usenko, Gig.Tr.Prof.Zabol., 8, 34-38 (1985)

4. V.A. Davali, V.I. Svidovyi, Gig.Sanit., 1, 40-43 (1992)

5. V.I. Svidovyi, O.I. Kuklina, Gig.Tr.Prof.Zabol., 6, 51-52 (1985)

6. O.A. Kazakov, Treatment by an infrasound and its other possibilities, 142 (The printer, Almaty, 1999)

7. G. Sverre, G.M. Orjan, Bio impedance and bioelectricity Basics second edition, 12-13 (Elsevier Linacre House, Jondan Hill, Oxford, 2008)

8. S.G. Gaidin, V.P. Zinchenko, I.Y. Teplov, S.T. Tuleukhanov, A.M. Kosenkov, Epilepsy Research, 158, 106224 (2019)

9. I.Y. Teplov, S.T. Tuleukhanov, V.P. Zinchenko, Biophysics (Russian Federation), 63(4), 566-575 (2018)

10. Z.B. Sabyrbek, S.T. Tuleukhanov, O.M. Alekseeva, Y.A. Kim, Modern Problems in Biochemical Physics: New Horizons, 281-292 (2012)

11. Zh.B. Sabyrbek, O.M. Alekseeva, S.T. Tuleukhanov, Yu.A. Kim, Bulletin of Experimental Biology and Medicine, 152(3), 353-356 (2012)

12. A.A. Mautenbaev, G.K. Atanbaeva, E.A. Kyrbassova et al., Journal of Pharmaceutical Sciences and Research, 10(12), 3214-3215 (2018) 
13. Z.Z. Ashirova, Z.Z. Kuzhantaeva, Z.S. Rakhimova, A.Z. Kuraspayeva et al., Journal of Pharmaceutical Sciences and Research, 10(12), 3261-3264 (2018)

14. E.A. Kyrbassova, G.U. Baitasheva et al., International Journal of Pharmaceutical Research, 10(4), 689-697 (2018)

15. A.M. Tatenov, S.T. Tuleuhanov, M.B. Amanbayeva, Research Journal of Medical Sciences, 9(4), 237-239 (2015) 